\title{
Anonim Ortaklık Esas Sermayesinin 0’a İndirilerek Eş Zamanlı Artırımının Şartı Olarak Mali Durumun İyileştirilmesi Amacı "X AG" Kararı (BGE 138 III 204)
}

\author{
Esra Bayar ${ }^{*}$ (1)
}

\author{
İsviçre Federal Mahkemesi'nin 13 Şubat 2012 tarihli kararı ${ }^{* *}$ \\ (4A 288/2011) - (4A 290/2011)
}

\section{Dava Konusu:}

\section{A. A.a}

5 Kasım 2004 tarihinde X Holding AG (X AG, Davalı) iflas halindeki bir işletmenin "kurtarılan ortaklığı" (“Auffanggesellschaft") olarak kurulmuştur. X Holding AG'nin 500.000- İsviçre Frank1 değerindeki esas sermayesi kuruluşta, her birisinin pay oranı $\% 10$ olmak üzere Z (Davacı) ile iki diğer ortak tarafindan ve pay oranı $\% 70$ olmak üzere Y tarafindan sağlanmıştır. Bu dört ortak kuruluştan itibaren davalı ortaklığın (X AG'nin) yönetim kurulunu oluşturmuşlardır. Davacı $(Z)$ ve bir diğer ortak gerekli know-how'1 temin ederlerken, Y yönetim kurulu başkanı görevinde yer almıştır. Davacı (Z) yönetim kurulu üyeliğine ilaveten kontrol işlevini üstlenmiş ve davalı ortaklığın (X AG'nin) ticari projelerinin yönetimi ve gözetimi ile görevlendirilmiştir. 2006 yılı sonunda davalı ortaklık (X AG) henüz kara geçememiştir. Borca batıklık nedeniyle İsviçre Borçlar Kanunu (İsvBK) md. 725/2'ye göre yönetim kurulu tarafından mahkemeye başvuru (zorunluluğu) tehlikesiyle karşı karşıyadır. (Aynı zamanda yönetim kurulu başkanı olan) Y'nin 4.900.000 İsviçre Frank1 değerindeki bir ortaklıktan olan alacağı için sırada sona gitmeyi kabul ettiğini açıklaması ile bu önlenmiştir. 


\section{A.b}

28 Aralık 2007 tarihli yazı ile yönetim kurulu başkanı (Y), 7 Ocak 2008 tarihinde gerçekleştirilecek yönetim kurulu toplantısı için çağrıda bulunmuştur. Yönetim kurulu toplantısının gündeminde; son yönetim kurulu toplantısının tutanağının kabulü, olağanüstü genel kurul çağrısında bulunulması ve ortaklığın sermayesinin azaltılmasıyla birlikte eş zamanlı olarak artırılması amacıyla olağanüstü genel kurul toplantısı gerçekleştirilmesi için yönetim kurulunun talebi yer almıştır. Çağrıya 31 Aralık 2007 tarihli bilanço ile kar ve zarar hesabı eklenmiştir. Yurtdışında olması sebebiyle davacı $(Z)$ yönetim kurulu toplantısına katılamamış, erteleme isteği reddedilmiştir. Söz konusu toplantıda yönetim kurulu, esas sermayenin azaltılmasını müteakip tekrar artırımı ve davacının (Z’nin) yönetim kurulundan ihracı amacıyla 18 Şubat 2008 tarihinde bir olağanüstü genel kurul toplantısı gerçekleştirilmesi kararlarını almıştır.

\section{A.c}

9 Ocak 2008 tarihli yazı ile ortaklara, 18 Şubat 2008 tarihinde gerçekleştirilecek olağanüstü genel kurul toplantı çağrısı gönderilmiştir. Gündem olarak esas sermayenin 0'a indirilerek doğrudan tekrar 500.000- Frank'a artırılması ve davacının (Z'nin) yönetim kurulundan ihracı belirtilmiştir. Aynı tarihli bir yazı ile olağanüstü genel kurul toplantısına binaen gerçekleştirilmesi gereken yönetim kurulu toplantısı için davet gönderilmiştir. Bu yönetim kurulu toplantısının gündeminde de yine son toplantı tutanağının kabulü, sermaye azaltımı uygulamasından sonra doğrudan gerçekleştirilecek sermaye artırımının icrasının tespit kararı, sermaye azaltımı ile sermayenin aynı esas sermaye değerine eş zamanlı olarak yeniden artırımının ticaret siciline tescil talebi yer almıştır.

\section{A.d}

29 Ocak 2008 tarihli yazı ile davalının (X AG’nin) ortaklarına, 18 Şubat 2008 tarihinde kararlaştırılacak olan esas sermayenin azaltımıyla eş zamanlı artırımı dikkate alınarak bir iştirak taahhütnamesi sunulmuştur. İlgili yazıda (esasa) dayanak olarak 18 Şubat 2008 tarihli olağanüstü genel kurul toplantısı dolayısıyla yapılması planlanan sermaye artırımı nedeniyle 8 Şubat 2008 tarihine kadar ortakların rüçhan haklarını hangi kapsam ve çerçevede kullanacaklarının sabit olması gerektiği sebep olarak gösterilmiştir. İştirak taahhütnamesi en geç 8 Şubat 2008 tarihine kadar ortaklığa geri gönderilmezse, ortakların rüçhan haklarını kullanmayacaklarının anlaşılacağı iletilmiştir. 1 Şubat 2008 tarihli yazı ile davacı (Z) yönetim kurulu başkanından, davalının ticari defter ve belgelerini görme talebinde bulunduğu gibi mali durumun iyileştirilmesi gerekliliğinin mevcudiyeti, nedenleri ve çerçevesi ile ilgili çeşitli sorularının cevaplandırılmasını istemiştir. 3 Şubat 2008 tarihli yazısı ile 
davacı (Z), soruları henüz cevaplandırılmamış olduğu için, o anda rüçhan hakkını kullanıp kullanmayacağının tespitini yapabilecek ne durumda ne de istekte olduğunu davalıya (XAG’ye) bildirmiştir. 18 Şubat 2008 tarihli yazısı ile yönetim kurulu başkanı davacının (Z'nin) sorularına cevap vermiş, çoğunlukla 2007 yılına ait yıllık (finansal) rapora atıfta bulunmuş ve sırada sona gitme sözleşmesinin hukuka uygunluğu, davacı ortağın (Z'nin) ortaklıktaki kontrol işlevi ve bu nedenle Holding'in finansal durumu hakkında bilgi sahibi olduğu hususlarını vurgulamıştır.

\section{A.e}

18 Şubat 2008 tarihinde davalı (ortaklığın) (X AG’nin) olağanüstü genel kurul toplantısı gerçekleştirilmiştir. Genel kurul toplantı tutanağına göre toplantıya tüm ortaklar ya aslen katılmışlar ya da toplantıda vekaleten temsil edilmişlerdir. Genel kurul toplantısına öncelikle 7 Ocak 2008 tarihinde hazırlanan 2007 yılına ait geçici bilanço sunulmuştur. Ne 2007 yılına ait kesin bilanço ne 31 Aralık 2007 tarihli y1llık (finansal) rapor ne de denetçi raporu sunulmuştur. Davalının (X AG'nin) beyanatlarına göre 2007 yılına ait geçici bilançoda 4.509.352 İsviçre Frankı sermaye kaybı olduğu gibi yaklaşık 184.000- İsviçre Frankı tutarında değer düzeltmeleri negatif sonucu ortaya çıkmıştır. Davacının (Z'nin) yönetim kuruluna yönelttiği 1 Şubat 2008 tarihli yazısındaki sorularına cevap talebi, hesap işlerinden sorumluluk ve kontrolörlük pozisyonu dolayısıyla 450'ye karş1 50 oy ile reddedilmiştir. Genel kurula, ortaklığın (X AG'nin) mali durumunun iyileştirilebilmesi için, gündemdeki "sermayenin azaltılarak eş zamanlı artırımı" ile birlikte amaçlanan diğer tedbirler hakkında herhangi bir bilgi sunulmamıştır. 18 Şubat 2008 tarihli noter tutanağına göre olağanüstü genel kurul 450 olumlu oya karş1 50 olumsuz oy ile şu kararları almıştır:

1. Nominal değerleri 1.000- İsviçre Frank1 olan toplam 500 adet nama yazılı pay senedinden oluşan 500.000- İsviçre Frankı tutarındaki esas sermayenin, tüm pay senetlerinin itfa edilmesi suretiyle 0 'a indirilmesi

2. Esas sermayenin nominal değerleri 1.000- İsviçre Frank1 olan 500 yeni nama yazılı pay senedi ihracı ile yeniden artırılması - sermaye borcu ödemesinin, bir ortağın 500.000- İsviçre Frankı tutarındaki ortaklıktan olan alacağının mahsup edilmesi yoluyla gerçekleştirilmesi - yeni ihraç edilecek pay senetlerinin, iştirakleri amacıyla mevcut ortaklara ortaklıktaki payları oranında sunulacağı ve kullanılmayan rüçhan haklarının yönetim kurulu tarafından mevcut ortaklara veya üçüncü kişilere tahsis edilebileceği

3. Azaltılan sermayenin mevcut sermaye miktarına (500.000- İsviçre Frank1) kadar tamamen ödenerek artırılması 
4. Yönetim kurulunun sermaye artırımının icrası ve ticaret siciline tescili için üç aylık kanuni süresi içerisinde uygun başvuruyu yapması için görevlendirilmesi

5. Davacının (Z'nin) yönetim kurulundan ihrac1

Yönetim kurulunun 18 Şubat 2008 tarihli sermaye artırım raporu, sermaye azaltımını müteakip gerçekleştirilen tekrar artırımı daha önce belirtilen çerçevede yazıya dökmüş, mevcut ortaklar lehine rüçhan haklarından kısaca bahsetmiş, sadece bir ortağın rüçhan hakkını kullandığını ve diğer ortakların rüçhan haklarının kullanılmasından vazgeçtiklerini tespit etmiştir. Kullanılmayan rüçhan hakları dolayısıyla kalan yeni pay senetleri, yönetim kurulu tarafından rüçhan hakkını kullanacağını bildiren ortağa ve üçüncü kişilere iştirakleri amacıyla sunulacaktır. 500 adet yeni nama yazılı pay senedi geçerli olarak ihraç edilmiş ve yeni esas sermayenin ödemesi ortaklık (X AG) ticari defterlerine göre bir ortağın (Y'nin) ortaklıktan olan 500.000- İsviçre Frankı tutarındaki bir alacağının mahsubu yoluyla gerçekleştirilmiştir. Davalının (X AG’nin) denetim organı 18 Şubat 2008 tarihli beyannamesiyle sermaye artırım raporunu imzalamıştır. 18 Şubat 2008 tarihli noter tutanağına göre yönetim kurulu olağanüstü genel kurul toplantısına binaen bundan sonra sermaye artırımının icrası kararını almıştır. Bunun sonucunda yönetim kurulu başkanı (Y) ortaklıktan olan 3.750.000- İsviçre Frankı tutarındaki bir alacağından vazgeçmiştir.

\section{A.f}

19 Şubat 2008 tarihli yazısıyla davacı (Z) yönetim kurulu başkanına (Y'ye), "ihtiyaten ve ön karar olmaksızın" rüçhan hakkını en azından bir pay senedi çerçevesinde kullanacağını bildirmiştir. Aynı zamanda davacı $(Z)$ olağanüstü genel kurul sonucunu ve işleyişini kabul etmediğini beyan etmiş ve sermaye artırımının ticaret siciline tescili için gerekli şartların oluşmadığını belirtmiştir. (Z) bu yazının bir örneğini $\mathrm{B}$. ticaret sicil müdürlüğünün bilgisine sunmuştur. Aynı gün davalı (X AG) 18 Şubat 2008 tarihli olağanüstü genel kurul kararlarının ticaret siciline tescili için B. ticaret sicil müdürlüğüne başvurmuştur. Ticaret sicil müdürlüğü davacının (Z'nin) yazısını davalının (X AG'nin) gerçekleştirdiği esas sermayenin azaltılması ile yeniden artırımına karşı itiraz olarak kabul etmiş ve 20 Şubat 2008 tarihli yazısı ile Bölge Mahkemesi'nden gerekli tedbirleri talep etmesi için davaciya (Z'ye) on günlük süre tanımıştır. Bölge Mahkemesi başkanının 29 Şubat 2008 tarihli ihtiyati kararı ile davacının (Z'nin) başvurusu kabul edilmiş ve B. ticaret sicil müdürlüğüne davalının (X AG’nin) olağanüstü genel kurul toplantısı ile bunu mütakip doğrudan gerçekleştirilen yönetim kurulu toplantısında alınan esas sermayenin itfa edilerek tekrar 500.000- İsviçre Frankı'na artırılmasına dair kararlarının ticaret siciline tescil edilmemesi bildirilmiştir. 27 Mayıs 2008 tarihinde, davalının (X AG’nin) savunmasından sonra, mahkeme başkanının kararıyla bu tescil yasağı kaldırılmıştır. 


\section{B. B.a}

17 Nisan 2008 tarihli dava dilekçesi ile davacı (Z) A. Bölge Mahkemesi'ne başvurarak şu taleplerde bulunmuştur:

18 Şubat 2008 tarihli noter tutanağının, davalının (X AG’nin) 18 Şubat 2008 tarihli olağanüstü genel kurul toplantısında alınan kararlarından, 1 (Sermaye Azaltımı), 2 (Sermayenin Tekrar Artırımı), 3 (Azaltılan Sermaye Kadar Sermaye Artırımı Ödemesinin) ve 4 (Sermaye Artırımının İcrasının) no'lu kararlarının butlanının tespit edilmesi gerekmektedir. Nihai olarak anılan kararların İsvBK md. 706 anlamında geçersizliğine hükmedilmeli ve geriye dönük olarak 18 Şubat 2008 tarihinden itibaren iptal edilmelidirler. Son olarak aynı tarihli resmi evraka göre davalının (X AG’nin) 18 Şubat 2008 tarihinde gerçekleştirilen yönetim kurulu toplantısında alınan kararlarının da yokluğunun tespit edilmesi gerekmektedir. 12 Aralık 2008 tarihinde davacı (Z) "4 no ile" yeni bir hukuki istem içeren yazılı dilekçesini sunmuştur: "4. Davalı (X AG) pay senetlerinin \%10'unu davaciya (Z’ye) tanımak ile yükümlendirilmelidir” 20 Nisan 2009 tarihli cevap dilekçesi ile davalı (X AG) 1slah isteminin reddedilmesini ve davanın "4 no'lu" hukuki isteminin kabul edilmemesini talep etmiştir. Diğer hususlar ile ilgili olarak dava reddedilmelidir. 24 Nisan 2009 tarihinde A. Bölge Mahkemesi başkanı davanın 1slahı ve "4 no'lu” hukuki isteminin kabul edilmemesiyle sınırlı bir ara karar düzenlemiştir. $\mathrm{Bu}$ ara kararda tarafların her istemi cevaplandırılmıştır. 3 Mart 2010 tarihli kararıyla A. Bölge Mahkemesi davayı tamamen reddetmiştir.

\section{B.b}

Bölge Mahkemesi’nin kararına karşı davacı (Z) 3 Mart 2010 tarihinde BaselLandschaft Kanton Mahkemesi'nde istinaf yoluna başvurmuştur. 27 Ağustos 2010 tarihli istinaf dilekçesinde, A. Bölge Mahkemesi'nin 3 Mart 2010 tarihli kararının bozulmasını ve 12 Aralık 2008 tarihli davanın sslahı isteminin kabul edilmesini talep etmiştir. Devamında ikinci derece yargılama sonucunda ortaya çıkan bütün olağan ve olağanüstü masraflar davalıya (X AG'ye) yükletilmelidir. 18 Ekim 2010 tarihli cevap dilekçesiyle istinaf yoluna cevap verilmiş, istinaf yoluna başvurunun reddedilmesi ve bir önceki yargı merciinin davayı reddetmesinin onanması talep edilmiştir. 18 Ocak 2011 tarihli kararıyla Kanton Mahkemesi istinaf yoluna başvuruyu masraflar yönünden kısmen kabul etmiştir.

\section{C.a}

Her iki taraf da Basel-Landschaft Kanton Mahkemesi kararını hukuki yönlerden temyiz etmişlerdir. Davacı (Z) (Dava 4A 290/2011) Federal Mahkeme'den, Kanton Mahkemesi'nin 18 Ocak 2011 tarihli kararının bozulmasını ve davasının kabul edilmesini talep etmiştir. Yani, 18 Şubat 2008 tarihli noter protokolüne göre davalının (X AG’nin) yönetim kurulu tarafından alınan tüm kararların yokluğunun olduğu 
gibi, aynı zamanda 18 Şubat 2008 tarihli noter tutanağının davalının olağanüstü genel kurul toplantısı kararlarının, 1 (Sermaye Azaltımı), 2 (Sermayenin Tekrar Artırımı), 3 (Azaltılan Sermaye Kadar Sermaye Artırımı Ödemesinin) ve 4 (Sermaye Artırımının İcrasının) no'lu bentlerine göre butlanının tespit edilmesi gerekmektedir. Nihai olarak anılan genel kurul toplantısı kararlarının İsvBK md. 706 anlamında geçersizliğine hükmedilmeli ve bunlar geriye dönük olarak 18 Şubat 2008 tarihinden itibaren olmak üzere iptal edilmelidirler. Davalı (X AG) (Dava 4A 288/2011) Federal Mahkeme'den, Kanton Mahkemesi'nin 18 Ocak 2011 tarihli kararının bozulmasını, A. Bölge Mahkemesi'nin 3 Mart 2010 tarihli kararının onanmasını talep etmiştir. Nihai olarak mesele yeni bir karar için bir önceki yargı merciine geri gönderilmelidir.

\section{C.b}

Davalı (X AG) davacının (Z’nin) temyizine karşı cevap dilekçesinde davanın reddini talep etmiştir. Davacı $(Z)$ temyiz isteminin kabulü sonucunda dava konusuz kalacağı için davalı tarafın temyiz isteminin reddini talep ettiği gibi temyiz istemlerinin birleştirilmesi talebinde bulunmuştur. Nihai olarak davalının (X AG'nin) temyiz istemi reddedilmelidir. Bir önceki yargı mercii her iki temyiz isteminin reddini talep etmiştir. Taraflar (4A 290/2011 no'lu) davada replik ve düplik dilekçelerini sunmuşlardır.

\section{Federal Mahkeme’nin Görüșü:}

1.

Aynı tarafların davaları - burada olduğu gibi - ile ilgili olduğunda ve itirazlar aynı maddi olaya dayandığında, Federal Mahkeme farklı dilekçeleri kural olarak tek bir kararda incelemektedir. Bundan dolayı söz konusu şartlarda her iki temyiz davasının, (4A 288/2011) ve (4A 290/2011) birleştirilmesi gerekmektedir.

\subsection{1}

Kanun yollarına müracaat usulünde son kanton mercii olarak değerlendirme yapan (BGG-[Bundesgerichtsgesetz]-Federal Mahkeme Kanunu md. 75) bir üst Kanton Mahkemesi'nin, bir hukuki konunun (BGG md.72) yargılaması sonucundaki kararının (BGG md. 90) iptali talep edilmektedir. Her iki taraf da kantonal yargılamada hukuki istemlerini tam olarak kabul ettirememişlerdir (BGG md. 76/1), dava konusunun değeri 30.000- İsviçre Frankının üzerindedir (BGG md.51 -bağlantılı olarak- BGG md.74/1/b) ve itiraz süresindedir (BGG md.100/1). Geçerli itirazlar ve yeterli hukuki dayanaklar saklı tutulmak şartıyla (BGG md. 42/2 ve md. 106/2) temyiz talepleri değerlendirilecektir. 


\section{2 .}

Federal Mahkeme kararını bir önceki yargı mercii tarafından tespit edilen somut olaya dayandırmıştır (BGG md. 105/1). Bu gerçek tespitlerden ancak, bunlar açıkça yanlışlarsa ya da BGG md. 95 anlamında bir hakkın ihlalinden ileri geliyorlarsa (BGG md. 105/2) ve eksikliğin ortadan kaldırılması davanın sonucu için belirleyici olabiliyorsa (BGG md. 97/1) ayrılınabilir. Açıkça yanlış olmaları, iradi olmaları anlamındadır (BGE 137 I 58 E. 4.1.2 S. 62, 136 II 304 E. 2.4 S. 313; atıflarıyla). Temyiz talebinde BGG md. 106/2'deki istemlere göre, bir önceki yarg1 mercii tarafından tespit edilen somut olayın hangi ölçüde BGG md. 105/2 anlamında bir eksiklik gösterdiği gerekçelendirilmelidir (BGE 133 II 249 E. 1.4.3 S. 254).

\section{3.}

Davac1 (Z) temyiz isteminde (4A 290/2011), bir önceki yargılama merciinin haksız olarak İsvBK md. 732a/1'e göre "sermayenin sıfira indirilerek eş zamanlı artırımı”nın ("Harmoni”) şartlarının yerine getirildiğini addettiğini ileri sürmüştür. Alınan "Harmoni” kararı "gereksiz bir bilanço makyajı" özelliği göstermekte ve bu haliyle hiçbir mali durumun iyileştirilmesi amacı ihtiva etmemektedir.

\section{1.}

İsvBK md. 621'e göre anonim ortaklık asgari esas sermaye miktarı 100.000İsviçre Frankıdır. Anonim ortaklık esas sermayesi sermaye azaltımı kapsamında yalnızca, asgari olarak 100.000- İsviçre Frank miktarına kadar eş zamanlı olarak yeni ve tamamen ödenmiş bir sermaye ile tamamlandikça, 100.000- Frank esas sermaye miktarının altına indirilebilmektedir (İsvBK md. 732/5). Esas sermaye, sermaye azaltımı kapsamında 0'a indirilerek bunu müteakip yeniden aynı miktara artırılırsa, "sermayenin sıfıra indirilerek eş zamanlı artırımı" ("Kapitalschnitt auf Null”) (krş. Peter Böckli, Schweizer Aktienrecht, 4. Bası, 2009, § 2 N 381a, 385) söz konusu olmaktadır. 1 Ocak 2008 tarihinde yürürlüğe giren İsvBK md. 732a ile kanun koyucu böyle bir "sermayenin sıfıra indirilerek eş zamanlı artırımı”nın geçerliliğini açıkça mali durumun iyileştirilmesi amacı için gerçekleştirilmesi halinde tanımaktadır. $\mathrm{Bu}$ halde İsvBK md. 732a/1'e göre ortakların mevcut pay sahipliği hakları sona ermektedir ve çıkarılmış pay senetleri itfa edilmek zorundadır. Bu hükümle kanun koyucu sermaye ortaklığında ortaklık kuruluşunun zorunlu olarak risk sermayesine iştirake bağlı olduğunu açıkça ortaya koymuştur. Bu risk sermayesi kaybedilirse, buna bağlı iştirak da bir son bulmak zorundadır (İsviçre Borçlar Kanunu Revizyonu Gerekçesi [Limited Ortaklıklar Hukuku hem de Anonim Ortaklıklar, Kooperatifler, Ticaret Sicili ve Marka Hukukunda Uyarlamalar], BBI 2002 3148, S. 3233; daha önceki hukuk için farklı olarak BGE 121 III 420 E. 4 S. 427 vd.). Bununla kanun koyucu ortağın kural olarak kendisinden alınamayacak ortaklık konumunun, 
sermayenin tamamının kaybı halinde, tekrar artırılan esas sermayeye iştiraki için ortağa sahip olduğu pay senetleri oranına göre kayıtsız şartsız ve geri alınamayacak bir hak sağladığını hesaba katmaktadır (İsvBK md. 732a/2; Gerekçe, S. 3234).

\section{2.}

İsvBK md. 732a/1'e göre "sermayenin sıfıra indirilerek eş zamanlı artırımı" imkanı, sermaye azaltımı ile birlikte sermaye artırımı kombinasyonunun mali durumun iyileştirilmesi amacına hizmet etmeleri hali ile sınırlıdır (krş. Gerekçe, S. 3233 vd.; Lukas Glanzmann, Fallstricke bei Gründung und Kapitalerhöhung, Kunz [Editör], Entwicklungen im Gesellschaftsrecht VI, Bern 2011, S. 30; eski hukuka göre durum için krş. BGE 86 II 78 E. 3 ve 4 S. 80 - 86; 121 III 420 E. 4 S. 427). Sadece mali durumun iyileştirilmesi ihtiyacı gösteren bir ortaklığın mali durumu iyileştirilebilir. İsvBK Gerekçesine göre "sermayenin sıfıra indirilerek eş zamanlı artırımı” kararı yalnızca, objektif bir değerlendirmede anonim ortaklığın esas sermayesi tamamen kaybedildiyse alınabilir (Gerekçe, S. 3233 vd.). İsvBK md. 725/2 anlamında bir borca batıklık durumunda bulunduğu gibi bir mali durumun iyileştirilmesi ihtiyacı bu şarta bağlıdır. Bir önceki yargılama merciinin tespitlerine göre davalının (X AG’nin) 2006 yılına ait (yıllık) hesabı 4.899.177- İsviçre Frankı tutarında bir bilanço kaybı ve 4.399.177- İsviçre Frankı tutarında bir negatif özsermaye değeri göstermektedir. Davalı 2007 yılında 390.000- İsviçre Frankı tutarında bir kar elde etmiş, ancak bununla herhangi bir değişiklik olmamış, 2008 yılının Şubat ayında (davalı X AG) daha önce olduğu gibi İsvBK md. 725/2 anlamında borca batıklık durumu arz etmiştir. Bununla da davalı, olağanüstü genel kurul toplantısı tarihi olan 18 Şubat 2008'de, mali durumun iyileştirilmesi ihtiyacı göstermiştir.

\section{3.}

Mali durumun iyileştirilmesi ihtiyacının varlığ "sermayenin sıfıra indirilerek eş zamanlı artırımı"nı tek başına mali durumu iyileştirme amacıyla bir tedbir haline getirmemektedir. Söz konusu olayda "esas sermayenin sıfira indirilerek" bunu müteakip tekrar esas sermaye miktarı olan 500.000- İsviçre Frankına artırılması davalının (X AG’nin) yaklaşık 4 milyon İsviçre Frankı tutarındaki borca batıklı̆̆ını sadece azaltabilmiş ancak hiçbir şekilde bertaraf edememiştir. Mali durumun iyileştirilmesi amacıyla bir tedbirden bahsedilebilip edilemeleyeceğinin sorulması gerekmektedir.

\subsection{1.}

İsvBK md. 732a/1'de yer alan mali durumun iyileştirilmesi amacı terimi Kanun'da ayrıntılı olarak tanımlanmamıştır. Öğretide İsvBK md. 725 'de yer alan mali durumun iyileştirilmesi terimine değinilerek, "Harmoni”nin İsvBK md. 725 anlamında gerçek 
bir mali durumun iyileştirilmesi sırasında uygulanması istenilmektedir (Böckli, § $2 \mathrm{~N}$ 388). Mali durumun iyileştirilmesinden ortaklığın finansal iyileşmesi için tüm tedbirler (BGE 121 III 420 E. 2b S. 424), yani ortaklığın devamının ve tasfiyenin engellenmesinin amaçlanması anlaşılmaktadır (Christoph B. Bühler, Sanierung der Aktiengesellschaft, Kunz [Editör], S. 39 vd.). Borca batıklık halinde mali durumun iyileştirilmesi tedbirlerinin kısa vadeli amacı ortaklığ en azından tüm sırada sona gitme açıklamalarından bağımsız olarak İsvBK md. 725 'e göre mahkemeye başvuruyu önleyebilecek duruma getirmektir. "Harmoni"nin, mali durumun iyileştirilmesi amac1 arz etmesi için, bu asgari amacı yerine getirmesi zorunludur.

\subsection{2}

"Harmoni" kapsamında alınan sermaye artırım kararı, borca batıklığı tamamen bertaraf eden bir sonuç doğuruyorsa, bu amaca herhangi başka bir tedbir olmaksızın ulaşılmaktadır. İsvBK md. 725/2'ye göre mahkemeye başvuruyu bir tarafa bırakmak için borca batıklığın gerçekten bertaraf edilmesi zorunlu şart değildir. Yargı kararlarına göre, ortaklığın yönetim organı derhal devamlı (kalıcı) bir mali durumu iyileştirme için makul beklentilere dayalı tedbirler alırsa, mahkemeye başvurulmasına gerek yoktur (BGE 132 III 564 E. 5.1 S. 573 atfiyla). Borca batıklığ 1 bertaraf etmek için sermaye artırımı tek başına yeterli olmazsa, "Harmoni", diğer başka tedbirlerle birlikte borca batıklığı bertaraf ederek mali durumun iyileşmesi sonucunu doğuruyorsa yine de mali durumun iyileştirilmesi amacı arz etmektedir (krş. Peter Forstmoser/HansUeli Vogt, Liberierung durch Verrechnung mit einer nicht werthaltigen Forderung: eine zulässige Form der Sanierung einer überschuldeten Gesellschaft?, ZSR 2003, S. 551). Bu halde "Harmoni”"nin mali durumu iyileștirme amacı devamlı (kalıc1) bir mali durumu iyileştirmeyi yerine getiren bir tedbirler paketi ile birlikte genişlemektedir.

\subsection{3}

Gerekli mali durumu iyileştirici tedbirleri hazırlamakla yükümlü yönetim kurulu (Wüstiner, Basler Kommentar, 3. Bası, 2008, N. 28 İsvBK md. 725 için), mali durumu iyileştirme amaciyla bir "Harmoni" uygulamak istiyorsa, bu, ya borca batıklığı doğrudan bertaraf etmek zorundadır ya da aynı zamanda diğer başka tedbirlerin de alınması zorunludur. Bunlar sermaye artırımı ile birlikte ortaklığın mali durumunun devamlı (kalıcı) olarak iyileştirilmesi için makul beklentileri ortaya koymak zorundadırlar. Yönetim kurulu tüm sırada sona gitme açıklamalarından bağımsız olarak kendisini İsvBK md. 725/2'ye göre mahkemeye başvurma yükümlülüğünden kurtaracak mali durumu iyileştirme planı belirlemek (yürütmek) zorundadır. "Sermayenin sıfıra indirilerek eş zamanlı artırımı" kararının alınması yetkisi genel kuruldadır (İsvBK md. 732/1). Mali durumun iyileştirilmesi için, bir tedbir olarak tek başına borca batıklığı bertaraf etmeyen bir "Harmoni" nin uygulanması gerekiyorsa, 
yönetim kurulu genel kurula bununla birlikte mali durumun iyileştirilmesi amacına ulaşmak için gerekli diğer tedbirler hakkında da bilgi vermek zorundadır. Yönetim kurulu genel kurula, karar almaya yetkili organ olması sebebiyle, uygun mali durumu iyileştirme planını sunmalıdır. Genel kurul bu plan hakkında bilgisi olmaksızın gündemdeki "Harmoni"nin bir mali durumu iyileștirme amacı arz edip etmediği değerlendirmesini yapamaz. Bununla birlikte, ortaklar da, mali durumu iyileştirme planı açıklaması olmaksızın, rüçhan haklarını kullanarak ortaklıkta yer almaya devam etmek isteyip istemedikleri hakkındaki bilgilendirilmiş kararlarını veremezler. Bu durumda (burada), İsvBK md. 732a/2'ye göre rüçhan hakkının geçersiz olarak sınırlandırılması bulunmaktadır.

\section{4}

Bir önceki yargı merciinin tespitlerine göre olağanüstü genel kurul toplantısında ortaklığın (X AG’nin) mali durumunun iyileştirilmesi için gerekli diğer başka tedbirler hakkında bilgi sunulmamıştır. Her şeyden önce bir ortağın ortaklıktan olan alacağının geri ödenmesinden vazgeçeceği beklentisi sunulmamıştır, nerede kaldı ki bir gerçek mali durumu iyileştirme planı sunulsun. Bu tespitler karşısında davalı ortaklığın (X AG’nin) iddiaları yeterli esasa dayalı somut olay itirazlarının yokluğuyla dikkate değer değildir (bkz. 2.2). Sermaye artırımı ile birlikte devamlı (kalıcı) bir mali durumu iyileştirme hakkında makul beklenti içeren diğer tedbirlerle ilgili olarak bilgi eksikliği nedeniyle 18 Şubat 2008 tarihinde toplanan olağanüstü genel kurul gündemindeki "Harmoni”nin mali durumu iyileştirme amacı arz edip etmediğini değerlendirememiştir. Ortaklar da, mali durumu iyileştirme planı hakkında bilgi sahibi olmadan, İsvBK md. 732a/2'ye göre rüçhan haklarını kullanarak ortaklıkta yer almaya devam etmek isteyip istemedikleri hakkındaki bilgilendirilmiş kararlarını verememişlerdir. İsvBK md. 732a/1'e göre "sermayenin sıfıra indirilerek eş zamanlı artırımı"nın koşulları oluşmamıştır, böylece alınan "Harmoni”" kararı hukuka aykırılık arz etmektedir.

\subsection{1}

İsvBK md. 706'ya göre yönetim kurulu ve her bir ortak Mahkeme'ye başvurarak Kanun'u veya ana sözleşmeyi ihlal eden genel kurul kararlarının iptali istemiyle ortaklığa karşı dava açabilirler (Fıkra 1). Özellikle Kanun'u veya ana sözleşmeyi ihlal eden ya da ortakların haklarını haksız yere kaldıran veya sınırlayan kararlar iptal edilebilirdirler (F1kra 2/1 ve 2). Bir genel kurul kararını iptal eden mahkeme kararı tüm ortaklar hakkında hüküm ve sonuç doğurmaktadır (F1kra 5). İptal edilen genel kurul kararlarını geriye dönük olarak iptal eden bir bozucu inşai hüküm söz konusudur (BGE 110 II 387 E. 2c S. 390). Dava, genel kurul toplantısından itibaren en geç iki ay içerisinde açılmazsa, iptal davası açma hakkı düşer (İsvBK md. 706a/1). 
İsvBK md. 706/b'ye göre genel kurul toplantısı kararları batıl da olabilmektedirler. Özellikle pay sahibinin kanundan kaynaklanan vazgeçilmez haklarını ortadan kaldıran veya sınırlandıran, pay sahibinin kontrol haklarını kanunen izin verilen ölçü dışında sınırlayan, anonim şirketin temel yapısını bozan veya sermayenin korunması düzenlemelerine aykırı olan kararlar batıldırlar (İsvBK md. 706b/1 - 3 ). İptali istenen söz konusu "Harmoni" kararı İsvBK md. 732a/1'e aykırı olması sebebiyle batıl değildir, ancak İsvBK md. 706/1'e göre kanuna aykırıdır. Davalı ortaklığın (X AG’nin) 18 Şubat 2008 tarihinde gerçekleştirilen olağanüstü genel kurul toplantısında alınan, iptali istenen kararlarından 1 (Sermaye Azaltımı), 2 (Esas Sermayenin Tekrar Artırımı), 3 (Azaltılan Sermaye Kadar Sermaye Artırımı Ödemesinin) ve 4 (Sermaye Artırımının İcrasının) no'lu kararlarının, iptal davasının genel kurul toplantısından itibaren iki aylık süre içerisinde açılmakla süresinde açıldığının kabul edilmesiyle birlikte, geriye dönük olarak iptal edilmesi gerekmektedir.

\section{2}

18 Şubat 2008 tarihli noter protokolüne göre, davalı ortaklığın (X AG’nin) yönetim kurulu tespit kararlarıyla, İsvBK md. 650/1 c.2'ye göre esas sermayenin tekrar artırılmasının icrası kararını almıştır. Böyle bir artırım icrası kararı uygun bir sermaye artırım kararına dayanmak zorundadır, bundan ayrılınamaz (İsvBK md. 650/1 c.1; Böckli, § 2 N 164, 166a; krş. BGE 132 III 668 E. 3.3.1 S. 675 vd.). İsvBK md. 714'e göre, genel kurul kararlarının butlanına dair hükümler kıyasen yönetim kurulu kararlarına uygulanırlar. Özellikle ağır bir şekilde Kanun'un (İsvBK) zorunlu ve temel hükümlerini ihlal eden yönetim kurulu kararları batıldırlar (BGE 133 III 77 E. 5 S. 79; 115 II 468 E. 3b S. 473 f.). Batıl bir kararın butlanının tespiti için dava açılabilir. Butlanı tespit eden mahkeme kararı herkes hakkında hüküm doğurur (Wernli, Basler Kommentar, 3. Bası, 2008, N. 7 İsvBK md. 714 için; Peter/Cavadini, Commentaire romand, 2008, N. 9 İsvBK md. 714 için). Genel kurulun "Harmoni” ye dair kararı hukuken geçersiz adledildikten sonra yönetim kurulunun 18 Şubat 2008 tarihli icra kararının temel hukuki dayanağı ortadan kalkmıştır. Genel kurulun geçerli bir artırım kararına uygun olarak yetkilendirilmemiş olması eksikliği nedeniyle, davalının yönetim kurulunun iptali istenen söz konusu icra kararı ağır bir eksiklik içermekte ve İsvBK md. 714'e göre yok hükmünde olmaktadır.

\section{5.}

18 Şubat 2008 tarihli noter protokolüne göre davalının (X AG'nin) yönetim kurulu tarafından alınan kararlarının yokluğu (temyiz isteminin $1 \mathrm{~b}$ ve 2 no'lu bentleri) ile davalının (X AG’nin) 18 Şubat 2008 tarihli olağanüstü genel kurulunda alınan 1-4 bentlerindeki kararlarının (geçersizliğinin) tespiti gibi geriye dönük olarak iptalini de talep eden davacının (Z'nin) temyiz istemi (4A 290/2011) esas itibariyle yerindedir. 
İptali için kanun yoluna başvurulan kararın bozulması ve davacının (Z’nin) temyiz talebinin $1 \mathrm{~b}$ ve 2 bentlerindeki istemlerinin kabul edilmesi gerekmektedir. Ayrıca meselenin kantonal yargılamanın masraf ve tazminat neticelerinin yeniden düzenlenmesi için bir önceki yargı merciine geri gönderilmesi gerekmektedir (BGG md. 67 ve md. 68/5). Kanun yoluna başvurulan kararın bozulmasıyla, davalının (X AG'nin) temyiz istemi (4A 288/2011) aleyhine olarak konusuz kalarak düşmüştür. Yargilama sonucuna göre davalı (X AG) Federal Mahkeme yargılamasının masraf ve tazminat borçları ile yükümlüdür (BGG md. 66/1 hem de md. 68/2).

Bu nedenle Federal Mahkeme Hükmü:

1. 4A 288/2011 no'lu dava ile 4A 290/2011 no'lu dava birleştirilmiştir.

2. Davacının (ortaklardan Z'nin) temyiz talebi (4A 290/2011) kabul edilmiş ve Basel-Landschaft Kanton Mahkemesi'nin 18 Ocak 2011 tarihli iptali istenen kararı bozulmuştur.

3. Davalının (X AG’nin) olağanüstü genel kurul kararları 18 Şubat 2008 tarihli Noter Protokolünün 1 (Sermaye Azaltımı), 2 (Esas Sermayenin Tekrar Artırımı), 3 (Azaltılan Sermaye Kadar Sermaye Artırımı Ödemesinin) ve 4 (Sermaye Artırımının İcrası) no'lu kararları geriye dönük olarak iptal edilmiştir.

4. 18 Şubat 2008 tarihli noter protokolüne göre davalının (X AG’nin) yönetim kurulu tarafından alınan kararların yok oldukları tespit edilmiştir.

5. Mesele kantonal yargılamanın masraf ve tazminat neticelerinin yeniden düzenlenmesi için bir önceki yargı merciine geri gönderilmiştir.

6. Davalının (X AG’nin) temyiz talebi (4A 288/2011) konusuz kalarak reddedilmiştir.

7. Toplam 10.000- İsviçre Frankı mahkeme masrafı davalı tarafa (X AG’ye) yükletilmiştir.

8. Davalı (X AG) federal yargılama için davacıya (Z'ye) 11.500- İsviçre Frankı tazminle yükümlüdür.

9. Bu Karar taraflara ve Basel-Landschaft Kanton Mahkemesi Hukuk Dairesine yazılı olarak tebliğ edilmiştir.

Lozan, 13 Şubat 2012 


\section{Kisaltmalar}

$\begin{array}{lll}\text { AG } & \text { (Aktiengesellschaft) } & \text { Anonim Ortaklık } \\ \text { BGE } & \text { (Bundesgerichtsentscheidung) } & \text { Federal Mahkeme Kararı } \\ \text { BGG } & \text { (Bundesgerichtsgesetz) } & \text { Federal Mahkeme Kanunu } \\ \text { c. } & \text { Cümle } & \\ \text { İsvBK } & \text { İsviçre Borçlar Kanunu } & \\ \text { krş. } & \text { Karş1laştırınız } & \\ \text { md. } & \text { Madde } & \\ \text { N } & \text { Kenar notu } & \\ \text { S. } & \text { Sayfa } & \\ \text { vd. } & \text { Ve devamı } & \end{array}$


